Review

\title{
Current and Emerging Therapies for Metastatic Castration-Resistant Prostate Cancer (mCRPC)
}

\author{
Iván Henríquez $^{1, *}$, Mack Roach III ${ }^{2}$, Todd M. Morgan ${ }^{3}{ }^{\mathbb{D}}$, Alberto Bossi ${ }^{4}$, Junior A. Gómez ${ }^{1}$, Oscar Abuchaibe ${ }^{5}$ \\ and Felipe Couñago 6 (D)
}

1 Department of Radiation Oncology, Hospital Universitario Sant Joan, 43204 Reus, Spain; junioranderson.gomez@gmail.com

2 UCSF Helen Diller Family Comprehensive Cancer Center, Department of Radiation Oncology, San Francisco, CA 94143, USA; mack.roach@ucsf.edu

3 Rogel Cancer Center, Department of Urology, University of Michigan, Ann Arbor, MI 48109, USA; tomorgan@med.umich.edu

4 Prostate Brachytherapy Unit, Department of Radiation Oncology, Genito Urinary Oncology, Goustave Roussy, 94805 Paris, France; Alberto.BOSSI@gustaveroussy.fr

5 Virgilio Galvis Ramirez Cancer Centre, Department of Radiation Oncology, Bucaramanga 681004, Colombia; oaabucha@hotmail.com

6 Department of Radiation Oncology, Clinical Department, Faculty of Biomedicine, Hospital Universitario Quirónsalud Madrid, Hospital La Luz, Universidad Europea, 28223 Madrid, Spain; fcounago@gmail.com

* Correspondence: ivanhenriquezlopez@me.com; Tel.: +34-655857839

Citation: Henríquez, I.; Roach, M., III; Morgan, T.M.; Bossi, A.; Gómez, J.A.; Abuchaibe, O.; Couñago, F. Current and Emerging Therapies for Metastatic Castration-Resistant Prostate Cancer (mCRPC). Biomedicines 2021, 9, 1247. https:// doi.org/10.3390/biomedicines 9091247

Academic Editor: Francesco Ceci

Received: 6 June 2021

Accepted: 11 September 2021

Published: 17 September 2021

Publisher's Note: MDPI stays neutra with regard to jurisdictional claims in published maps and institutional affiliations.

Copyright: (C) 2021 by the authors. Licensee MDPI, Basel, Switzerland. This article is an open access article distributed under the terms and conditions of the Creative Commons Attribution (CC BY) license (https:// creativecommons.org/licenses/by/ $4.0 /$ )

\begin{abstract}
Metastatic castration-resistant prostate cancer (mCRPC) encompasses a heterogeneous wide range of molecular tumor behavior and a high risk of progression. Early detection and treatment are therefore crucial in these patients. Treatment has improved drastically in recent years and many novel therapeutic agents are currently under investigation. However, due to the rapidly changing therapeutic landscape in $\mathrm{MCRPC}$, it is difficult for clinicians to keep up to date with the latest innovations in this area. In the present narrative review, we discuss the current and emerging therapies for $\mathrm{mCRPC}$ as well as the clinical and molecular factors that can help predict which patients are most likely to benefit from these novel agents.
\end{abstract}

Keywords: mCRPC; prostate cancer; androgen deprivation therapy; novel therapies

\section{Introduction}

Prostate cancer (PCa) is one of the most common cancers in men. In the year 2020, an estimated 191,000 new cases of PCa were diagnosed in the United States (USA) with more than 33,000 deaths. In that same year, 449,761 new diagnoses were recorded in Europe, with more than 100,000 deaths [1,2].

At diagnosis, most patients have localized disease. However, $5 \%$ of patients are diagnosed with metastatic disease and $30-40 \%$ of patients will develop biochemical recurrence after treatment (surgery and/or radiotherapy) [2]. A substantial proportion of these patients will develop metastatic castration-resistant prostate cancer (mCRPC). The long-term prognosis for patients with $\mathrm{mCRPC}$ is poor, with a relatively short overall survival (OS), although survival varies highly depending on individual disease characteristics [2-4].

Since the introduction of docetaxel in 2004, there has been a surge in novel treatments for $\mathrm{mCRPC}$, including new cytostatic agents, second-generation antiandrogens, bonetargeted therapies, immunotherapy, poly (adenosine diphosphate-ribose) polymerase (PARP) inhibitors, Akt inhibitors, and radioisotopes. These advances have improved survival in patients with mCRPC while also improving quality of life (QoL).

Due to the rapidly changing therapeutic landscape in $\mathrm{MCRPC}$, it is difficult for clinicians to keep up to date with the latest innovations in this area. Consequently, the aim of the present narrative review is to review the currently available evidence on novel and 
emerging therapies for the treatment of mCRPC. In recent years, new treatments have been developed for non-metastatic CRPC, but this type of CRPC is beyond the scope of the present narrative review.

\section{Methods}

\subsection{Castration-Resistant Prostate Cancer}

Most men with advanced disease eventually stop responding to traditional androgendeprivation therapy (ADT) and are thus categorized as CRPC, which is defined as prostate cancer that progresses clinically, radiographically, or biochemically despite castration levels of serum testosterone. Imaging tests may be indicated to monitor for signs of distant metastases. Factors that determine how often imaging should be performed include individual risk, age, overall patient health, prostate-specific antigen (PSA) velocity, and Gleason score [5]. CRPC is defined as a documented rise in PSA $\geq 2 \mathrm{ng} / \mathrm{mL}$, PSA values $>25 \%$ above nadir, PSA elevation in three consecutive determinations at least one week apart, and/or radiological progression in castrated patients with serum testosterone levels $<50 \mathrm{ng} / \mathrm{dL}(<1.7 \mathrm{nmol} / \mathrm{L})[5,6]$.

\subsection{Search Strategy, Data Acquisition, and Risk of Bias}

We conducted a systematic review of the literature using the Embase, PubMed, and Scopus electronic databases. We searched for relevant articles published in those databases between January 2010 and December 2020 using the following search terms: "advanced prostate cancer"; "metastatic castration resistant prostate cancer"; "randomized studies"; "chemotherapy"; " androgen deprivation therapy"; "immunotherapy"; "second-generation antiandrogens"; "radiopharmaceuticals"; "PARP inhibitors"; "radioisotopes"; "AKT inhibitors"; and "bone-targeted therapy". We included original articles published in English, studies reporting oncologic outcomes, biochemical failure, progression-free survival (PFS), cancer-specific mortality, OS, and/or patient-reported side effects. We included both randomized controlled trials (RCTs) and controlled (nonrandomized) clinical trials. We excluded cross-sectional studies, case series, case reports, and articles published by the same group of researchers with possible data overlap. We also checked the references included in the selected articles to locate other studies not identified in the initial search. The studies with the highest level of evidence were evaluated and selected for inclusion in this review by consensus agreement among the researchers. The Cochrane risk tool was used to evaluate the risk of bias in the clinical trials [7].

\section{Current Treatments in mCRPC}

Most men with PCa will eventually develop disease progression despite castration. Two trials have shown only a marginal survival benefit for patients remaining on LHRH analogues during second- and third-line therapies [8,9]. However, in the absence of prospective data, the modest potential benefits of continuing agonists or antagonists to suppress testosterone to castration levels outweigh the minimal risks of treatment. Since then, all clinical trials conducted at CRPC include ADT as part of baseline treatment (Table 1).

Table 1. Current treatments in mCRPC.

\begin{tabular}{|c|c|c|c|c|c|c|c|c|}
\hline Therapy & Type & Study Design & $\begin{array}{l}\text { Trial } \\
\text { Name }\end{array}$ & $\begin{array}{c}\mathrm{N} \\
\text { Patients }\end{array}$ & $\begin{array}{l}\text { Trial } \\
\text { Phase }\end{array}$ & $\begin{array}{l}\text { Efficacy } \\
\text { OS } \\
\text { (Months) }\end{array}$ & $\begin{array}{c}\text { Adverse Events } \\
\text { G3-4 }\end{array}$ & Comments \\
\hline \multirow[t]{2}{*}{ Chemotherapy } & Docetaxel & $\begin{array}{l}\text { MTX + PRD vs. } \\
\text { DOC + PRD }\end{array}$ & TAX327 & 1006 & III & 18.9 vs. 16.5 & $26 \%$ & $\begin{array}{l}\text { DOC improves OS } \\
\text { and symptoms }\end{array}$ \\
\hline & Cabazitaxel & $\begin{array}{c}\text { CBZ + PRD vs. } \\
\text { MTX + PRD } \\
\text { CBZ20 + PRD vs. } \\
\text { CBZ25 + PRED } \\
\text { vs. DOC }\end{array}$ & $\begin{array}{l}\text { TROPIC } \\
\text { FIRSTANA }\end{array}$ & $\begin{array}{c}755 \\
1168\end{array}$ & $\begin{array}{l}\text { III } \\
\text { III }\end{array}$ & $\begin{array}{l}15.1 \text { vs. } 12.7 \\
25.2 \text { vs. } 24.3\end{array}$ & $\begin{array}{c}82 \% \text { neutropenia } \\
\quad 41.2-60.1 \%\end{array}$ & $\begin{array}{l}\text { CBZ improves OS after } \\
\text { DOC-based therapy } \\
\text { CBZ20/25 is not } \\
\text { superior to DOC }\end{array}$ \\
\hline
\end{tabular}


Table 1. Cont.

\begin{tabular}{|c|c|c|c|c|c|c|c|c|}
\hline Therapy & Type & Study Design & $\begin{array}{l}\text { Trial } \\
\text { Name }\end{array}$ & $\begin{array}{c}\mathrm{N} \\
\text { Patients }\end{array}$ & $\begin{array}{l}\text { Trial } \\
\text { Phase }\end{array}$ & $\begin{array}{c}\text { Efficacy } \\
\text { OS } \\
\text { (Months) }\end{array}$ & $\begin{array}{c}\text { Adverse Events } \\
\text { G3-4 }\end{array}$ & Comments \\
\hline \multirow[t]{2}{*}{$\begin{array}{c}\text { Second- } \\
\text { generation } \\
\text { antiandrogens }\end{array}$} & Abiraterone & $\begin{array}{c}\text { AB + PRD vs. } \\
\text { Placebo + PRD } \\
\text { AB + PRD vs. } \\
\text { Placebo + PRD }\end{array}$ & $\begin{array}{l}\mathrm{COU} / 301 \\
\mathrm{COU} / 302\end{array}$ & $\begin{array}{l}1195 \\
1088\end{array}$ & $\begin{array}{l}\text { III } \\
\text { III }\end{array}$ & $\begin{array}{l}14.8 \text { vs. } 10.9 \\
34.7 \text { vs. } 30.3\end{array}$ & $\begin{array}{l}55 \% \text { vs. } 43 \% \\
48 \% \text { vs. } 42 \%\end{array}$ & $\begin{array}{c}\text { AB improves OS after } \\
\text { DOC treatment } \\
\text { AB improves OS in } \\
\text { chemotherapy- } \\
\text { naive patients }\end{array}$ \\
\hline & Enzalutamide & $\begin{array}{c}\text { ENZA vs. } \\
\text { Placebo } \\
\text { ENZA } \\
\text { vs. Placebo }\end{array}$ & $\begin{array}{l}\text { AFFIRM } \\
\text { PREVAIL }\end{array}$ & $\begin{array}{l}1199 \\
1717\end{array}$ & $\begin{array}{l}\text { III } \\
\text { III }\end{array}$ & $\begin{array}{l}18.4 \text { vs. } 13.6 \\
32.4 \text { vs. } 30.2\end{array}$ & $\begin{array}{l}45 \% \text { vs. } 53 \% \\
43 \% \text { vs. } 37 \%\end{array}$ & $\begin{array}{l}\text { ENZ improves OS } \\
\text { after chemotherapy } \\
\text { ENZ improves OS in } \\
\text { chemotherapy- } \\
\text { naïve patients }\end{array}$ \\
\hline Radiopharmaceuticals & Radium-223 & $\begin{array}{c}\text { Ra- } 223 \text { vs. } \\
\text { Placebo } \\
\text { Ra- } 223+\mathrm{AB} \\
\text { vs. } \mathrm{AB}\end{array}$ & $\begin{array}{l}\text { ALSYMPCA } \\
\text { ERA }\end{array}$ & $\begin{array}{l}921 \\
806\end{array}$ & $\begin{array}{l}\text { III } \\
\text { III }\end{array}$ & $\begin{array}{l}14.9 \text { vs. } 11.3 \\
30.7 \text { vs. } 33.3\end{array}$ & $\begin{array}{c}56 \% \text { vs. } 62 \% \\
28.6 \% \text { vs. } 11.4 \% \text { * }\end{array}$ & $\begin{array}{c}\text { Ra-223 improves OS } \\
\text { Ra-223 + AB did not } \\
\text { improve SSE-free } \\
\text { survival and increased } \\
\text { bone fractures }\end{array}$ \\
\hline
\end{tabular}

Key: N, number; AB, Abiraterone; CBZ, Cabazitaxel; ENZA, Enzalutamide; DOC, Docetaxel; MTX, Mitoxantrone; PRD, Prednisone; OS, Overall survival; SSE, Symptomatic skeletal event. * Bone fracture risk.

\subsection{Chemotherapy}

\subsubsection{Docetaxel}

Since the year 2004, several clinical trials have been conducted to evaluate the efficacy of docetaxel, a cytotoxic agent of the taxane family, in mCRPC. In the first phase III trial, TAX327 [10], a total of 1006 patients with $\mathrm{mCRPC}$ were randomized to receive docetaxel + prednisone (DP) in two different regimens (three times weekly at $75 \mathrm{mg} / \mathrm{m}^{2}$, or weekly at $30 \mathrm{mg} / \mathrm{m}^{2}$ ) or mitoxantrone + prednisone (MP). OS was longer in the threeweekly DP arm versus the MP arm (median survival: 18.9 vs. 16.5 months, respectively; hazard ratio [HR]: 0.76, $p=0.009)$. However, no differences in OS were observed between the weekly DP arm and MP. Secondary outcomes such as prostate-specific antigen (PSA) response rate, pain reduction, and QoL measured by the FACT-P questionnaire, were also better in the three-weekly DP arm. The most common treatment-related toxicities associated with DP were alopecia (65\%), asthenia (53\%), nausea (42\%), diarrhea (32\%), and neuropathy $(30 \%)$. The incidence of grade $3 / 4$ neutropenia was $32 \%$, with $26 \%$ of patients experiencing at least one severe adverse event.

Another phase III trial in the same subgroup of patients compared docetaxel + estramustine (DE) versus MP [11], showing that OS was better in the group that received DE. However, due to the severe toxicity profile of estramustine, which includes a risk of thrombotic events and cardiovascular toxicity, this agent is no longer used. In an attempt to find a regimen with more manageable toxicity, a phase II trial was performed to compare the classical three-weekly regimen of $75 \mathrm{mg} / \mathrm{m} 2$ of DE compared to a dose of $50 \mathrm{mg} / \mathrm{m}^{2}$ delivered on days one and 14 of the 28-day cycle [12]. All patients received $10 \mathrm{mg}$ of oral prednisolone daily. The primary outcome measure-time to treatment failure-was superior in the twice-monthly DP arm (5.6 vs. 4.9 months; HR 1.3, 95\% confidence interval [CI]: $1.1-1.6, p=0.014)$, with a longer OS (19.5 vs. 17 months; HR 1.4, 95\% CI: 1.1-1.8, $p=0.021$ ). There was also less toxicity in the twice-monthly arm, with a decrease in both hematologic and digestive toxicity (diarrhea, nausea). Therefore, the five-weekly DP regimen can be considered a valid treatment option, especially in frail patients given the important need to limit the toxicity in these patients.

\subsubsection{Cabazitaxel}

Cabazitaxel is another member of the taxane family that has proven effective even in docetaxel-resistant cancers. The results of the pivotal phase III TROPIC trial were reported in 2010 [13]. In that trial, which included 775 patients with mCRPC who had received prior treatment with docetaxel, patients were randomized to cabazitaxel + prednisone (CP) or MP. OS was significantly longer in the CP arm (15.1 vs. 12.7 months, HR 0.7, $p<0.0001)$, with a greater PSA response and longer PFS. Severe toxicity associated with the 
$\mathrm{CP}$ regimen was mainly hematologic, most commonly neutropenia ( $94 \%$ of patients), grade $3 / 4$ neutropenia $(82 \%)$, and febrile neutropenia $(8 \%)$. The most important non-hematologic toxicities were diarrhea ( $47 \%$ of patients; $6 \%$ grade $3-4)$, nausea $(34 \% ; 2 \%$ grade $3-4)$, and fatigue (37\%; 5\% grade $3-4$ ). Based on those findings, CP became the standard treatment option for patients with progression after prior DP.

The phase III FIRSTANA trial was performed to evaluate whether cabazitaxel $20 \mathrm{mg} / \mathrm{m}^{2}$ (C20) or $25 \mathrm{mg} / \mathrm{m}^{2}$ (C25) was superior to docetaxel $\left(75 \mathrm{mg} / \mathrm{m}^{2}\right)$ in terms of OS as a first-line treatment of mCRPC. However, there were no significant differences between the two treatment regimens [14]. Median OS for the higher dose regimen (C25) was 25.2 months versus 24.3 months for docetaxel (HR 0.97; 95\% CI: $0.82-1.16, p=0.757$ ). Another phase III trial was performed to assess the possibility of administering cabazitaxel at a lower dose (20 mg/m $\mathrm{m}^{2}$ versus the standard dose of $\left.25 \mathrm{mg} / \mathrm{m}^{2}\right)$, as part of the PROSELICA study [15]. OS rates were similar, but with less toxicity in the low dose arm, thus indicating that the $20 \mathrm{mg} / \mathrm{m}^{2}$ dose was a safe and effective option in these patients.

\subsection{Second-Generation Antiandrogens}

The development of second-generation antiandrogens showed that a large percentage of prostate cancers remain dependent on androgen signaling, even at the low serum testosterone levels present after castration. As a result, the term "castration-resistant" came to replace the classical terms "hormone-refractory" or "hormone-independent".

\subsubsection{Abiraterone}

Abiraterone is an androgen biosynthesis inhibitor that functions by inhibiting two of the main enzymes (17-alpha-hydroxylase and 17,20-lyase) involved in PCa. These enzymes are necessary for androgen biosynthesis in testicular, suprarenal, and prostate tumor tissues. Given that abiraterone can lead to a rebound effect due to hyperactivation of the mineralocorticoid axis, it should be administered in combination with prednisone.

Continuous CYP17 inhibition raises levels of adrenocorticotropic hormone (ACTH), which increases steroid levels upstream of CYP17, including corticosterone and deoxycorticosterone. These raised upstream steroids prevent adrenocortical insufficiency but can result in a syndrome of secondary mineralocorticoid excess characterized by fluid retention, hypertension, and hypokalemia. This can be ameliorated by low-dose glucocorticoids, which decrease ACTH and steroids upstream of the CYP17 blockade. Prednisone is a synthetic corticosteroid metabolized to prednisolone (active form) in the liver [16].

Publication of the phase III trial COU-AA-301 in 2011 led to the approval of abiraterone as a treatment for mCRPC [16]. In that trial, 1195 patients who had progressed after treatment with docetaxel were randomized to abiraterone + prednisone or placebo + prednisone. Median OS (the primary outcome measure) was significantly longer in the abiraterone arm (14.8 vs. 10.9 months, HR $0.65, p<0.001$ ). In addition, secondary outcome measures (PSA response rate, time to PSA progression, and PFS) were all better in the abiraterone arm. Treatment-related toxicity, mainly due to hyperstimulation of the mineralocorticoid axis, included arterial hypertension (10\%; grade 3-4: 1\%), hypokalemia (17\%: grade 3-4: 3\%), and water retention (33\%; grade 3-4: $2 \%$ ). Patients in the abiraterone arm developed more heart conditions (mainly arrhythmias) than those who received placebo, but this difference was not statistically significant. Other adverse effects-including nausea, asthenia, pain, and elevated transaminase levels-were significantly more common in the treatment arm.

The results of another phase III trial (COU-AA-302) [17] were reported in 2012. That study included 1088 asymptomatic or mildly symptomatic chemotherapy-naïve (including docetaxel) patients diagnosed with mCRPC. Patients were randomized to receive abiraterone + prednisone or placebo + prednisone. The results showed a clear benefit for abiraterone in terms of both rPFS (16.5 vs. 8.3 months, HR $0.53, p<0.001)$ and OS (34.7 vs. 30.3 months; HR 0.81; $p=0.0033$ ). No new toxicities or a higher rate of previously described toxicities were observed with longer exposure to the drug. Based on these 
findings, abiraterone + prednisone became the new standard of care for mCRPC in patients with and without prior chemotherapy.

\subsubsection{Enzalutamide}

Enzalutamide is an androgen receptor antagonist with three different mechanisms of action: (1) it prevents the binding of testosterone and its metabolites to the androgen receptor; (2) it prevents translocation into the nucleus, and (3) it blocks binding to DNA, thus inhibiting its activity as a transcription factor. Importantly, enzalutamide does not have any agonistic activity and induces apoptosis in prostate cancer cell lines.

The development of enzalutamide paralleled that of abiraterone. The first phase III trial of this agent in the treatment of mCRPC (the AFFIRM trial), reported in 2012, was conducted in a post-docetaxel setting in a large sample $(n=1199)$ of patients [18]. Patients were randomized to receive enzalutamide or placebo, with significantly longer OS in the treatment arm (18.4 vs. 13.6 months, HR 0.63, $p<0.001)$. Secondary outcome measuresincluding PSA response rate, time to PSA progression, and radiographic PFS-were all better in the patients who received enzalutamide. In terms of adverse effects, enzalutamide was associated with neurotoxicity (convulsions), but in less than $1 \%$ of patients. There was also a higher incidence of arterial hypertension ( $6 \%$ vs. 3\%), asthenia (34\% vs. 29\%), and hot flushes ( $20 \%$ vs. $10 \%$ ) in the treatment arm.

The results of the phase III PREVAIL trial were reported in 2014 [19]. That trial was performed to evaluate enzalutamide administered before docetaxel versus placebo, in a study design that was similar to the COU-AA-302 trial with abiraterone. Compared to placebo, a higher proportion of patients in the enzalutamide arm achieved radiographic PFS at 12 months (65\% vs. 14\%, HR 0.19, $p<0.001)$ and OS was also significantly longer in the experimental arm (32.4 vs. 30.2 months, HR $0.7, p<0.001)$. The most common adverse events in the enzalutamide arm were asthenia, hot flushes, and hypertension, but there was no clear increase in convulsions in the treatment arm versus placebo. Based on the finding of that clinical trial, enzalutamide became one of the standard hormonotherapy options in patients with mCRPC regardless of prior treatment with docetaxel.

\subsection{Radiopharmaceuticals}

\section{Radium-223}

Radiopharmaceuticals-primarily beta emitters, such as strontium or samariumhave long been prescribed, mainly for the palliative treatment of bone pain. Although these radiopharmaceuticals were effective for pain relief, they had no impact on survival. Radium-223 is a calcium mimetic alpha emitter that accumulates in the bone with a very low capacity to penetrate surrounding tissues, but greater cytotoxic capacity due to its higher linear energy transfer.

In 2013, the results of the pivotal phase III ALSYMPCA trial comparing Radium-223 to placebo in patients with $\mathrm{mCRPC}(\mathrm{n}=921)$ with symptomatic bone involvement but no evidence of visceral involvement was reported [20]. Patients had previously received docetaxel or were not eligible to receive it. The primary outcome measure was OS, which was significantly better in the Radium-223 group (14.9 vs. 11.3 months, HR 0.7, $p<0.001$ ). Secondary outcome measures-time to first symptomatic bone event, time to alkaline phosphatase elevation, and QoL [21] —were all significantly better in the experimental arm. Interestingly, the toxicity profile was also better in the Radium-223 arm, with less overall toxicity than in the placebo arm, except for thrombopenia (12\%; $6 \%$ grade $3-4)$, neutropenia $(5 \% ; 3 \%$ grade $3-4)$ and diarrhea $(25 \% ; 2 \%$ grade $3-4)$. Based on these findings, Radium- 223 became a standard treatment option in patients with mCRPC with bone metastases (but not visceral metastases).

The phase III ERA-223 trial [22] evaluated Radium-223 in combination with abiraterone and prednisone versus placebo for the treatment of asymptomatic or mildly symptomatic chemotherapy-naive mCRPC. The combined treatment significantly increased the fracture risk (28.6\% vs. $11.4 \%$ ) and also reduced the mean survival time (30.7 vs. $33.3 \mathrm{~m}$ ) 
compared to placebo. Based on an unplanned analysis of the ERA-223 trial, the Pharmacovigilance Risk Assessment Committee of the European Medicines Agency (EMA) concluded that the combination of Radium-223 and abiraterone was contraindicated, leading to an official recommendation against this combination in the European Union (EU) [22,23]. in the EU, Radium-223 is now indicated for use after at least two prior lines of systemic therapy for mCRPC (excluding LHRH analogues) or for patients who are ineligible for other systemic treatments [24]. Notably, the indication for Radium-223 remains unchanged in many countries, including the United States, Canada, Switzerland, and Japan.

\section{Emerging Treatments in mCRPC}

Numerous different treatments have been evaluated for mCRPC, but none have demonstrated any overall survival benefit. Several promising drugs currently in development could emerge as new alternative therapies in the near future for patients with mCRPC, as we discuss below (Table 2).

Table 2. Emerging therapies in mCRPC.

\begin{tabular}{|c|c|c|c|c|c|c|c|c|}
\hline Therapy & Type & Study Design & Trial Name & $\begin{array}{c}\mathrm{N} \\
\text { Patients }\end{array}$ & $\begin{array}{l}\text { Trial } \\
\text { Phase }\end{array}$ & $\begin{array}{c}\text { Efficacy } \\
\text { OS (Months) }\end{array}$ & $\begin{array}{l}\text { Adverse } \\
\text { Events } \\
\text { G3-4 }\end{array}$ & Comments \\
\hline $\begin{array}{c}\text { PARP } \\
\text { inhibitors }\end{array}$ & Olaparib & $\begin{array}{l}\text { Olaparib vs. } \\
\text { ENZA or AB }\end{array}$ & PROFOUND & 387 & III & 18.5 vs. 15.1 & $51 \%$ vs. $38 \%$ & $\begin{array}{l}\text { Olaparib improves PFS, } \\
\text { measures of response and } \\
\text { patient-reported end } \\
\text { points in those with } \\
\text { alterations in genes with a } \\
\text { role in homologous } \\
\text { recombination repair }\end{array}$ \\
\hline \multirow[t]{3}{*}{ Immunotherapy } & Sipileucel-T & $\begin{array}{l}\text { Sipileucel vs. } \\
\text { placebo }\end{array}$ & IMPACT & 512 & III & 25.8 vs. 21.7 & $\begin{array}{l}31.7 \% \text { vs. } \\
35.1 \%\end{array}$ & $\begin{array}{l}\text { Sipuleucel-T improves OS. } \\
\text { No effect on time to } \\
\text { disease progression }\end{array}$ \\
\hline & Ipilimumab & $\begin{array}{c}\text { RT }+ \\
\text { Ipilimumab vs. } \\
\text { RT + Placebo } \\
\text { Ipilimumab vs. } \\
\text { Placebo }\end{array}$ & $\begin{array}{l}\text { CA184-043 } \\
\text { CHEMO- } \\
\text { NAIVE }\end{array}$ & $\begin{array}{l}799 \\
602\end{array}$ & $\begin{array}{l}\text { III } \\
\text { III }\end{array}$ & $\begin{array}{l}11.2 \text { vs. } 10.0 \\
28.7 \text { vs. } 29.7\end{array}$ & $\begin{array}{l}26 \% \text { vs. } 3 \% \\
40 \% \text { vs. } 6 \%\end{array}$ & $\begin{array}{l}\text { NO differences in OS } \\
\text { Ipilimumab did not } \\
\text { improve OS, but did } \\
\text { improve PFS and PSA } \\
\text { response }\end{array}$ \\
\hline & Atezolizumab & $\begin{array}{l}\text { Atezolizumab } \\
+ \text { ENZA vs. } \\
\text { ENZA }\end{array}$ & $\begin{array}{l}\text { IMBASSADOR } \\
250\end{array}$ & 759 & III & 16.6 vs. 15.2 & $54 \%$ vs. $35 \%$ & $\begin{array}{l}\text { Atezolizumab did not } \\
\text { improve OS }\end{array}$ \\
\hline Radioisotopes & $\begin{array}{l}\left.{ }^{177} \mathrm{Lu}\right] \mathrm{Lu}- \\
\text { PSMA-617 }\end{array}$ & $\begin{array}{c}{\left[{ }^{177} \mathrm{Lu}\right] \mathrm{Lu}-} \\
\text { PSMA-617 vs. } \\
\text { CBZ } \\
{\left[{ }^{177} \mathrm{Lu}\right] \mathrm{Lu}-} \\
\text { PSMA-617 vs. } \\
\text { Standard care }\end{array}$ & $\begin{array}{l}\text { THERAP } \\
\text { VISION }\end{array}$ & $\begin{array}{c}291 \\
1179\end{array}$ & $\begin{array}{l}\text { II } \\
\text { III }\end{array}$ & $\begin{array}{l}65 \% \text { vs. } 37 \% * \\
15.3 \text { vs. } 11.3 \\
8.7 \text { vs. } 3.4^{* * *}\end{array}$ & $\begin{array}{c}33 \% \text { vs. } 53 \% \\
52.7 \% \text { vs. } 38 \%\end{array}$ & $\begin{array}{c}{\left[{ }^{177} \mathrm{Lu}\right] \mathrm{Lu}-\mathrm{PSMA}-617 \mathrm{had}} \\
\text { better PSA response and } \\
\text { fewer toxicity than CBZ } \\
{\left[{ }^{177} \mathrm{Lu}\right] \mathrm{Lu}-\mathrm{PSMA}-617} \\
\text { prolonged PFS and OS }\end{array}$ \\
\hline $\begin{array}{c}\text { AKT } \\
\text { inhibitors }\end{array}$ & Ipatasertib & $\begin{array}{l}\text { Ipatasertib + } \\
\text { Placebo vs. } \\
\text { Ipatasertib + } \\
\text { AB }\end{array}$ & $\begin{array}{l}\text { IPATENTIAL } \\
150\end{array}$ & 253 & II & 18.9 vs. 15.6 & $\begin{array}{l}64.3 \%, 50.6 \% \text { ** } \\
\text { vs. } 35.4 \%\end{array}$ & $\begin{array}{l}\text { Ipatasertib + AB showed } \\
\text { better antitumor activity } \\
\text { in PTEN-loss tumors }\end{array}$ \\
\hline
\end{tabular}

Key: * PSA response rate; ** Ipatasertib, 400 mg and 200 mg, respectively; *** PFS; AB Abiraterone; CBZ Cabazitaxel; ENZA Enzalutamide; PFS Progression-free survival; PSA Prostate-specific antigen.

\subsection{DNA Repair Gene Mutations}

Somatic mutations in DNA repair pathway genes occur in up to $23 \%$ of mCRPC tumors (19\% of localized prostate tumors), with most mutations found in BRCA2 and ATM [25]. These mutations are often associated with germline mutations. One study found that $42 \%$ of patients with mCRPC (and $60 \%$ of patients with localized PCa) who had the BRCA2 mutation carried this mutation in their germlines [26].

Germline DNA repair mutations have been reported in approximately $10 \%$ of men with metastatic PCa [27]. In men with germline BRCA mutations, prostate cancer appears to develop earlier, with a more aggressive phenotype associated with significantly reduced survival times than in non-carriers [28]. Most scientific societies and clinical guidelines recommended genetic testing based on family history, histology, and risk groups for patients with PCa and any of the following (based on germline genetic testing): a positive 
family history, high-risk or very high-risk disease, regional or metastatic PCa (regardless of family history), Ashkenazi Jewish ancestry, and intraductal/cribriform histology. Germline testing should include MLH1, MSH2, MSH6, and PMS2 (for Lynch syndrome), and the homologous recombination genes BRCA2, BRCA1, ATM, PALB2, and CHEK2 [29,30]. Somatic tumor testing based on risk groups is recommended for patients with regional (N1) and metastatic PCa. Somatic testing should include BRCA1, BRCA2, ATM, PALB2, FANCA, RAD51D, CHEK2, and CDK12. In patients with metastatic castration-naïve and mCRPC, microsatellite instability (MSI-H) and mismatch repair-deficient (dMMR) should be included [29-31]. Genetic counseling and support are essential; when possible, pre-test counseling is advised, particularly in patients with a family history of the disease [31].

\subsubsection{PARP Inhibitors}

PARP inhibitors, which have been approved for the treatment of other solid cancers such as ovarian cancer, are in advanced stages of development as a treatment for PCa. The mechanism of action of these agents is based on alterations in DNA repair mechanisms. As a treatment for $\mathrm{mCRPC}$, the most advanced trial of PARP inhibitors is the phase III PROFOUND trial [32] involving patients with mCRPC with genetic alterations in DNA damage repair mechanisms (mainly BRCA1, BRCA2, and ATM). The PROFOUND trial compared olaparib (a PARP inhibitor) to the standard treatment selected by the study investigators. Patients in the experimental arm had a significantly better response rate (33\% vs. $2 \%$; OR: 20.86 ; 95\% CI: 4.18 to $379.18, p<0.001$ ), PFS (7.4 vs. 3.6 months; HR 0.34; $95 \%$ CI: 0.25 to $0.47 ; p<0.001)$, and OS (18.5 vs. 15.1 months). Subsequently, olaparib was approved by the United States Food and Drug Administration (FDA). Olaparib is now included in both the NCCN and APCCC guidelines [33,34], and germline and somatic testing for relevant alterations are now considered standard of care for these patients.

Recently, talazoparib was assessed in an open-label phase 2 trial (TALAPRO-1) in patients with mCRPC and DDR-HRR alterations [35]. In that trial, 128 patients (all of whom had received one or two taxane-based chemotherapy cycles and progressed on enzalutamide or abiraterone, or both) received oral talazoparib until disease progression. After a median follow-up of 16.4 months (interquartile range: 11.1-22.1), the objective response rate was $29.8 \%$ (95\% CI: $21.2-39.6)$. The most common grade $3-4$ treatmentemergent adverse events were anemia (31\%), thrombocytopenia (9\%), and neutropenia $(8 \%)$. Serious adverse events were reported in $34 \%$ of patients. Talazoparib showed durable antitumor activity in these heavily pretreated patients with $\mathrm{mCRPC}$ and DDR-HHR gene alterations.

Several clinical trials are currently underway to assess the role of other drugs in the same class as olaparib (rucaparib and niraparib) for the treatment of mCRPC as well as in earlier stages of PCa. However, several questions remain to be resolved, including whether all genetic alterations in DNA repair mechanisms are predictors of the efficacy of PARP inhibitors and the clinical setting in which these drugs are likely to be most beneficial.

\subsubsection{Platinum-Based Chemotherapy for DNA Repair Defects}

Emerging evidence suggests that the status of the DNA damage-repair pathway influences sensitivity to platinum-based chemotherapy. Patients with BRCA1 or BRCA2 mutations have a defect in homologous DNA recombination, making cells that harbor these mutations susceptible to DNA damaging agents, such as cisplatin or carboplatin [36]. A retrospective analysis of 141 men with $\mathrm{mCRPC}$ treated with $\geq$ two doses of carboplatin and docetaxel at the Dana Farber Cancer Institute between 2001-2015 found that treatment benefits for patients with germline BRCA2 mutations [37]. Six of the eight BRCA2 carriers $(75 \%)$ had a decrease in PSA $>50 \%$ within the first 12 weeks of starting this regimen compared to 23 of 133 non-carriers $(17 \%)(p=0.001)$. A decrease in PSA $>50 \%$ was associated with longer survival (18.9 months in BRCA2 carriers vs. 9.5 months in noncarriers). Several studies are currently underway to evaluate the role of platinum-based chemotherapy in patients with DNA repair defects. 


\subsection{Immunotherapy}

Many investigators believe that PCa is immunologically cold (i.e., low immune sensitivity), as this type of cancer has fewer somatic mutations than other cancers and thus a lower immunogenicity level. Notwithstanding this unique characteristic, other features of PCa suggest that immunotherapy could be beneficial, including the slow growth of these tumors and the presence of antigenic expression of prostatic acid phosphatase (PAP), PSA, and prostate-specific membrane antigen (PSMA).

Although immunotherapy now forms part of the therapeutic arsenal for several cancers, its role in the treatment of PCa is not clear. The results of a phase III trial (IMPACT) comparing Sipuleucel-T-an autologous, dendritic cell-based vaccine- to placebo were published in 2010 [38]. Sipuleucel-T increased OS versus placebo ( 25.8 vs. 21.7 months; $\mathrm{HR}, 0.78 ; 95 \% \mathrm{CI}: 0.61$ to $0.98, p=0.03$ ) in asymptomatic or mildly symptomatic patients with mCRPC without prior chemotherapy. However, due to doubts about its efficacy, manufacturing challenges, and associated costs, this treatment has not yet been approved by any European regulatory agency. Although it has been approved in the USA by the FDA, its use in clinical settings remains relatively limited.

The use of targeted therapies such as cytotoxic T-lymphocyte antigen (anti-CTLA-4) or programmed cell death 1 (anti-PD-1) and its ligand (PD-L1), have not had much success to date in mCRPC. Phase III trials comparing ipilimumab $[39,40]$ or anti-CTLA-4 to placebo in docetaxel-naive patients ( 28.7 vs. 29.7 months; HR, 1.11; 95.87\%CI, 0.88 to $1.39 ; p=0.3667$ ) and in those who switched to docetaxel (11.2 vs. 10 months; HR, $0.85,0.72-1-00 ; p=0.053$ ) show no improvement in survival. The results of the IMbassador250 trial [41], which compared enzalutamide alone to enzalutamide + atezolizumab in patients with mCRPC, were also negative (OS: 16.6 vs. 15.2 months; HR, 1.12; 95\% CI: 0.91 to $1.37 ; p=0.28$ ).

The prevalence of high MSI-H/dMMR prostate cancer [40], and the clinical utility of immune checkpoint blockade are unknown. Pembrolizumab, an anti- PD-1 antibody, seems to be effective in MSI-H/dMMR CRPC. In one study, 54.5\% of patients (6/11) treated with anti-PD-1/PD-L1 had a greater than $50 \%$ decline in PSA levels, and four of these patients also had a confirmed radiographic response [42].

Cyclin-dependent kinase (CDK12) alterations are reported to occur in $4-11 \%$ of PCa [25] cases and are more common in the mCRPC setting. Importantly, the CDK12mutant genomic signature is mutually exclusive and distinct from dMMR subtypes of PCa. It has been hypothesized that focal tandem duplication-induced genomic instability represents a therapeutic vulnerability due to the formation of fusion-related immunogenic neoantigens [25]. If this hypothesis is validated, this would have implications beyond $\mathrm{PCa}$, as it would represent a potentially novel tumor-agnostic application for immunotherapy [25]. However, although a large number of trials are currently evaluating these drugs, the findings reported to date do not show a significant impact on OS, which is why these agents are not included among the standard treatment options.

\subsection{Radioisotopes}

In recent years, interest in the role of antibodies-mainly those targeting PSMA linked to radioisotopes such as lutetium and actinium - has increased substantially. Lutetium177 [ $\left.{ }^{177} \mathrm{Lu}\right] \mathrm{Lu}-\mathrm{PSMA}-617$ is a radiolabeled small molecule that delivers $\beta$ radiation to cells expressing PSMA. This agent has been shown to present clinical activity in patients with mCRPC, and can be administered safely [43,44]. A phase II trial [45] comparing $\left[{ }^{177} \mathrm{Lu}\right] \mathrm{Lu}-\mathrm{PSMA}-617$ to cabazitaxel in patients with mCRPC showed that $\left[{ }^{177} \mathrm{Lu}\right] \mathrm{Lu}-$ PSMA-617 achieved a greater PSA response (65\% vs. $37 \%, 95 \%$ CI: $16-42 ; p<0.0001)$ with fewer grade $3 / 4$ adverse events (33\% vs. $53 \%$ ). A recently published randomized open-label, phase III trial [46] (VISION trial) evaluated treatment with 177Lu-PSMA-617 in patients with mCRPC previously treated with at least one androgen receptor pathway inhibitor and one or two taxane regimens. All patients had a PSMA-positive gallium-68 (68Ga)-labeled PSMA-11 positron emission tomography-computed tomography scan. The alternate primary end points were imaging-based PFS and OS. Of the 1179 screened pa- 
tients, 831 underwent randomization. The median follow-up was 20.9 months. Compared to standard care alone, the addition of 177Lu-PSMA-617 to standard care significantly prolonged both imaging-based PFS (median: 8.7 vs. 3.4 months; HR for progression or death, $0.40 ; 99.2 \%$ CI, 0.29 to $0.57 ; p<0.001$ ) and OS (median: 15.3 vs. 11.3 months; HR for death, $0.62 ; 95 \%$ CI, 0.52 to $0.74 ; p<0.001)$. The incidence of $\geq$ grade 3 adverse events was higher with 177Lu-PSMA-617 than without it (52.7\% vs. 38.0\%), but QoL was not adversely affected.

Based on the results of that trial, the authors concluded that $\left[{ }^{177} \mathrm{Lu}\right] \mathrm{Lu}-\mathrm{PSMA}-617$ is an effective new therapeutic class and a potential alternative to taxanes regimens.

\subsection{AKT Inhibitors}

AKT is part of the PI3K-AKT-mTOR pathway, acting as a regulator of cellular metabolism. Loss of function of the PTEN tumor suppressor, resulting in dysregulated activation of the PI3K signaling network, is recognized as one of the most common driving events in prostate cancer development. PTEN loss is highest in aggressive metastatic disease, and therefore, efforts to find available inhibitors of specific components of the PI3K/PTEN/TOR signaling network in PCa treatment is a challenge [47].

The results of the phase III IPATential150 trial were recently presented at the annual congress of the European Society of Medical Oncology [48]. That trial compared first-line abiraterone + placebo to abiraterone + ipatasertib (an AKT inhibitor) in patients with mCRPC. Radiographic PFS in patients with PTEN loss (the primary outcome measure) was significantly better in the combined treatment arm (HR, 0.39; 90\% CI, 0.22-0.7). Although follow-up is still ongoing, the available data in the intention-to-treat population shows no significant between-group differences in radiographic PFS or OS (18.9 vs. 15.6 months, $\mathrm{HR}, 0.72 ; 90 \% \mathrm{CI}, 0.47-1.11, p=0.22$ ). However, these data suggest that, in the future, PTEN status may play an important role in selecting potential candidates for this therapeutic strategy.

\section{Therapeutic Sequencing in $\mathrm{mCRPC}$}

At present, for most patients, no clear predictors of response are available, which makes it difficult to determine the most suitable treatment for each patient to consider personalized treatment. Exceptions to this include BRCA1-2 mutations and alterations in genes related to PARP inhibitors or PTEN loss, as well as MSI-H mutations.

Currently, there is no optimal therapeutic sequence for all patients. Numerous factors must be considered in each case, including the patient's overall health, the presence of comorbidities, previous treatments (and the efficacy and toxicity thereof), patient preferences, and the availability of clinical trials at each center. As a result, although general recommendations can be made, these must be tailored to the needs and characteristics of the individual patient. In fact, the clinical evidence shows that the patient's individual characteristics (e.g., performance status; comorbidities; degree of frailty; and symptoms) play a crucial role in treatment selection. Thus, the various treatment options, including the efficacy and toxicity profile of the drug, should be evaluated only after carefully considering the patient's individual clinical profile.

In the clinical trials conducted to date, first-line treatment for patients with asymptomatic or mildly symptomatic mCRPC has generally involved novel hormonal agent such as abiraterone or enzalutamide (when not contraindicated). However, in certain casessuch as in patients with high Gleason scores, visceral involvement, a short-lived response to prior androgen deprivation therapy, or only slightly elevated PSA levels with large tumor volumes-direct treatment with chemotherapy (docetaxel) can be considered given that those factors are usually associated with a poor response to hormonal therapy [49].

The available data suggest that the sequential delivery of two different hormonal agents provides little benefit. Numerous phase II trials have shown that sequential administration of abiraterone and enzalutamide (regardless of the order and regardless of previous treatment with another chemotherapy agent) is associated with poor PSA re- 
sponse and minimal gains in PFS [50]. These findings were confirmed in 2019 with the publication of the phase III CARD trial [51]. That trial involved patients with mCRPC who had been previously treated with docetaxel and either abiraterone or enzalutamide who developed disease progression within 12 months of receiving these agents. The patients were randomized to receive cabazitaxel ( $25 \mathrm{mg} / \mathrm{m} 2$ intravenously every 3 weeks) plus daily prednisone and granulocyte colony-stimulating factor or the other inhibitor (either $1000 \mathrm{mg}$ of abiraterone plus prednisone daily or $160 \mathrm{mg}$ of enzalutamide daily). The cabazitaxel arm had better OS (13.6 vs. 11 months; HR, $0.64 ; 95 \%$ CI: 0.46 to $0.89 ; p=0.008$ ), PFS (4.4 vs. 2.7 months; HR, 0.52 ; $95 \%$ CI: 0.40 to $0.68 ; p<0.001$ ), and PSA response rates $(35.7 \%$ vs. $13.5 \%)$ than placebo. Pain control was also better with cabazitaxel. The $\geq$ G3 adverse event rate was similar ( $56.3 \%$ vs. $52.4 \%$ ). The findings of that trial confirmed that these patients obtain a greater benefit from chemotherapy than from a second hormone therapy. Despite those findings, we do not recommend hormonal therapy sequencing in most mCRPC patients. At the end, the effects of therapeutic sequencing in PCa can be affected by incorporating several of these agents during earlier stages of the disease (metastatic hormone-naive PCa or non-metastatic CRPC) [52].

\section{Bone-Targeted Therapy}

Prostate cancer tropism towards the bone explains high incidence rate $(90 \%)$ of bone metastases in the castration-resistant phase. Preventing skeletal-related events (SRE) is crucial to avoid pathologic fractures, medullar compression, and the need for additional treatment (radiotherapy and/or surgery), all of which are associated with increased morbidity and lower QoL in these patients.

Zoledronic acid, a potent third-generation IV bisphosphonate (inhibitor of osteoclastic activity) has been shown to significantly reduce the risk of SREs in patients with mCRPC ( $44 \%$ vs. $32 \%$ with placebo) [53] and may even delay the emergence of these events. Although this drug was approved by regulatory agencies in 2004, it has not been shown to improve survival outcomes [53].

Denosumab is a human monoclonal antibody to RANKL (an osteoclastosis activator) that significantly suppresses bone resorption. It has been approved by the FDA and the EMA for the prevention of SREs in patients with bone metastases from solid tumors. However, similar to zoledronic acid, it does not improve OS. A study comparing zoledronic acid to denosumab found that the latter drug was superior in terms of toxicity profile [54].

\section{Conclusions}

The treatment of metastatic castration-resistant prostate cancer has changed considerably in recent years with the development of systemic treatments that improve both survival and QoL outcomes. However, due to a lack of validated biomarkers and robust predictors to help select the optimal treatment, these systemic therapies must be selected on a case-by-case basis in accordance with the patient's individual characteristics and preferences. Treatment selection must also consider prior therapies and access to clinical trials. The therapeutic arsenal for $\mathrm{mCRPC}$ is expected to change significantly in coming years as several new treatments and novel biomarkers are incorporated into routine clinical practice. Ultimately, these developments are expected to allow clinicians to offer patients a truly personalized treatment approach.

Author Contributions: I.H. and F.C. conceived the idea for this review; I.H., F.C., M.R.III, T.M.M., A.B., J.A.G. and O.A. wrote the manuscript. All authors have read and agreed to the published version of the manuscript.

Funding: This research received no external funding.

Institutional Review Board Statement: Not applicable.

Informed Consent Statement: Not applicable. 
Data Availability Statement: Data sharing not applicable. No new data were created or analyzed in this study.

Conflicts of Interest: The authors declare no conflict of interest.

\section{References}

1. Siegel, R.L.; Miller, K.D.; Goding Sauer, A.; Fedewa, S.A.; Butterly, L.F.; Anderson, J.C.; Cercek, A.; Smith, R.A.; Jemal, A. Cancer statistics, 2020. CA Cancer J. Clin. 2020, 70, 145-164. [CrossRef] [PubMed]

2. El Cáncer en Cifras-SEOM: Sociedad Española de Oncología Médica (c) 2019 [Internet]. [Citado 23 de Diciembre de 2020]. Available online: https://seom.org/prensa/el-cancer-en-cifras (accessed on 17 December 2020).

3. Valero, J.; Peleteiro, P.; Henriquez, I.; Conde, A.; Piquer, T.; Lozano, A.; Soler, C.C.; Muñoz, J.; Llescas, A.; Jove, J.; et al. Age, Gleason and PSA are important prognostic factors for survival in metastático castration-resistant prostate cancer. Results of the Uroncor Group (Uro-Oncological Tumors) of the Spanish Society of Radiation Oncology (SEOR). Clin. Transl. Oncol. 2020, 22, 1378-1389. [CrossRef] [PubMed]

4. Scher, H.I.; Solo, K.; Valant, J.; Todd, M.B.; Mehra, M. Prevalence of Prostate Cancer Clinical States and Mortality in the United States: Estimates Using a Dynamic Progression Model. PLoS ONE 2015, 10, e0139440. [CrossRef]

5. Scher, H.I.; Morris, M.J.; Stadler, W.M.; Higano, C.; Basch, E.; Fizazi, K.; Antonarakis, E.S.; Beer, T.M.; Carducci, M.A.; Chi, K.N.; et al. Trial Design and Objectives for Castration-. Prostate Cancer: Updated Recommendations from the Prostate cancer Clinical Trials Working Group 3. J. Clin. Oncol. 2016, 34, 1402-1418. [CrossRef]

6. Gómez-Caamaño, A.; González-San Segundo, C.; Henríquez, I.; Maldonado, X.; Zapatero, A. Consensus on management of castration-resistant prostate cancer on behalf of the Urological Tumours working Group (URONCOR) of the Spanish society of radiation oncology. Clin. Transl. Oncol. 2019, 21, 420-432. [CrossRef] [PubMed]

7. Higgins, J.P.; Altman, D.G.; Gøtzsche, P.C.; Jüni, P.; Moher, D.; Oxman, A.D.; Savovic, J.; Schulz, K.F.; Weeks, L.; Sterne, J.A.C. The Cochrane collaboration's tool for assessing risk of bias in randomised trials. BMJ 2011, 343, d5928. [CrossRef]

8. Hussain, M.; Wolf, M.; Marshall, E.; Crawford, E.D.; Eisenberger, M. Effects of continued androgen-deprivation therapy and other prognostic factors on response and survival in phase II chemotherapy trials for hormone-refractory prostate cancer: A Southwest Oncology Group report. J. Clin. Oncol. 1994, 12, 1868-1875. [CrossRef] [PubMed]

9. Taylor, C.D.; Elson, P.; Trump, D.L. Importance of continued testicular suppression in hormone-refractory prostate cancer. J. Clin. Oncol. 1993, 11, 2167-2172. [CrossRef]

10. Tannock, I.F.; De Wit, R.; Berry, W.R.; Berry, W.R.; Horti, J.; Pluzanska, A.; Chi, K.N.; Oudard, S.; Théodore, C.; James, N.D.; et al. Docetaxel plus prednisone or mitoxantrone plus prednisone for advanced prostate cancer. N. Engl. J. Med. 2004, 351, 1502-1512. [CrossRef] [PubMed]

11. Petrylak, D.P.; Tangen, C.M.; Hussain, M.H.; Lara J, P.N.; Jones, J.A.; Taplin, M.E.; Burch, P.A.; Berry, D.; Moinpour, C.; Kohli, M.; et al. Docetaxel and estramustine compared with mitoxantrone and prednisone for advanced refractory prostate cancer. N. Engl. J. Med. 2004, 351, 1513-1520. [CrossRef]

12. Kellokumpu-Lehtinen, P.L.; Harmenberg, U.; Joensuu, T.; McDermott, R.; Hernoven, P.; Ginman, C.; Luukkaa, M.; Nyandoto, P.; Hemminki, A.; Nilsson, S.; et al. 2-weekly versus 3-weekly docetaxel to treat castration-resistant advanced prostate cancer: A randomized, phase 3 trial. Lancet Oncol. 2013, 14, 117-124. [CrossRef]

13. De Bono, J.S.; Oudard, S.; Ozguroglu, M.; Hansen, S.; Machiels, J.P.; Kocak, I.; Gravis, G.; Bodrogi, I.; Mackenzie, M.J.; Shen, L.; et al. Prednisone plus cabazitaxel or mitoxantrone for metastatic castration-resistant prostate cancer progressing after docetaxel treatment: A randomized open-label trial. Lancet 2010, 376, 1147-1154. [CrossRef]

14. Oudard, S.; Fizazi, K.; Sengeløv, L.; Daugaard, G.; Saad, F.; Hansen, S.; Hjälm-Eriksoon, M.; Jassem, J.; Thiery-Vuillemin, A.; Caffo, O.; et al. Cabazitaxel versus docetaxel as first-line therapy for patients with metastatic castration-resistant prostate cancer: A randomized phase III trial-FIRSTANA. J. Clin. Oncol. 2017, 35, 3189-3197. [CrossRef]

15. Eisenberger, M.; Hardy-Bessard, A.C.; Kim, C.S.; Géczi, L.; Ford, D.; Mourey, L.; Carles, J.; Parente, P.; Font, A.; Kacso, G.; et al. Phase III study comparing a reduced dose of cabazitaxel $\left(20 \mathrm{mg} / \mathrm{m}^{2}\right)$ and the currently approved dose $\left(25 \mathrm{mg} / \mathrm{m}^{2}\right)$ in postdocetaxel patients with metastatic castration-resistant prostate cancer-PROSELICA. J. Clin. Oncol. 2017, 35, 3198-3206. [CrossRef] [PubMed]

16. De Bono, J.S.; Logothetis, C.J.; Molina, A.; Fizazi, K.; North, S.; Chu, L.; Chi, K.N.; Jones, R.J.; Goodman, O.B.; Saad, F.; et al. Abiraterone and increased survival in metastatic prostate cancer. N. Engl. J. Med. 2011, 364, 1995-2005. [CrossRef]

17. Ryan, C.J.; Smith, M.R.; De Bono, J.S.; Molina, A.; Logothetis, C.J.; De Souza, P.; Fizazi, K.; Maiwaring, P.; Piulats, J.M.; Ng, S.; et al. Abiraterone in metastatic prostate cancer without previous chemotherapy. N. Engl. J. Med. 2013, 368, 138-148. [CrossRef]

18. Scher, H.I.; Fizazi, K.; Saad, F.; Taplin, M.E.; Sternberg, C.N.; Miller, K.; De Wit, R.; Mulders, P.; Chi, K.N.; Schore, N.D.; et al. Increased survival with enzalutamide in prostate cancer after chemotherapy. N. Engl. J. Med. 2012, 367, 1187-1197. [CrossRef] [PubMed]

19. Beer, T.M.; Armstrong, A.J.; Rathkopf, D.E.; Loriot, Y.; Sterberng, C.N.; Higano, C.S.; Iversen, P.; Bhattacharya, S.; Carles, J.; Chowdhury, S.; et al. Enzalutamide in metastatic prostate cancer before chemotherapy. N. Engl. J. Med. 2014, 371, 424-433. [CrossRef] [PubMed]

20. Parker, C.; Nilsson, S.; Heinrich, D.; Helle, S.I.; O’Sullivan, J.M.; Fosså, S.D.; Chodacki, A.; Wiechno, P.; Logue, J.; Seke, M.; et al. Alpha emitter radium-223 and survival in metastatic prostate cancer. N. Engl. J. Med. 2013, 369, 213-223. [CrossRef] [PubMed] 
21. Nilsson, S.; Cislo, P.; Sartor, O.; Vogelzang, N.J.; Coleman, R.E.; O'Sullivam, J.M.; Reuning-Scherer, J.; Schan, M.; Zhan, L.; Parker, C. Patient-reported quality-of-life analysis of radium-223 dichloride from the phase III ALSYMPCA study. Ann. Oncol. 2016, 27, 868-874. [CrossRef]

22. Smith, M.R.; Parker, C.C.; Saad, F.; Miller, K.; Tombal, B.; Ng, Q.S.; Bögemman, M.; Matveev, V.; Piulats, J.M.; Zucca, L.E.; et al. ERA 223: A phase 3 trial of radium-223 (Ra-223) in combination with abiraterone acetate and prednisone/prednisolone for the treatment of asymptomatic or mildly symptomatic chemotherapy-naïve patients with mCRPC. In Proceedings of the ESMO Congress, Munich, Germany, 19-23 October 2018.

23. European Medicines Agency (EMA). EMA restricts use of prostate cancer medicine Xofigo. In Proceedings of the EMA Restricts Use of Prostate Cancer Medicine Xofigo, London, UK, 28 September 2018.

24. O'Sullivan, J.M.; Carles, J.; Cathomas, R.; Gomez-Iturriaga, A.; Heinrich, D.; Kramer, G.; Ost, P.; van Oort, I.; Tombal, B. Radium-223 Within the Evolving Treatment Options for Metastatic Castration-resistant Prostate Cancer: Recommendations from a European Expert Working Group. Eur. Urol. Oncol. 2020, 3, 455-463. [CrossRef]

25. Robinson, D.; Van Allen, E.M.; Wu, Y.M.; Schultz, N.; Lonigro, R.J.; Mosquera, J.M.; Montgomery, B.; Taplin, M.E.; Pritchard, C.C.; Attard, G.; et al. Integrative clinical genomics of advanced prostate cancer. Cell 2015, 161, 1215-1228. [CrossRef] [PubMed]

26. Cancer Genome Atlas Research Network. The Molecular Taxonomy of Primary Prostate Cancer. Cell 2015, 163, 1011-1025. [CrossRef]

27. Castro, E.; Romero-Laorden, N.; Del Pozo, A. PROREPAIR-B: A Prospective Cohort Study of the Impact of Germline DNA Repair Mutations on the Outcomes of Patients with Metastatic Castration-Resistant Prostate Cancer. J. Clin. Oncol. 2019, 37, 490-503. [CrossRef] [PubMed]

28. Wei, Y.; Wu, J.; Gu, W.; Wang, J.; Lin, G.; Qin, X.; Dai, B.; Gan, H.; Ye, D.; Zhu, Y. Prognostic Value of Germline DNA Repair Gene Mutations in De Novo Metastatic and Castration-Sensitive Prostate Cancer. Oncologist 2020, 25, e1042-e1050. [CrossRef] [PubMed]

29. Cheng, H.H.; Sokolova, A.O.; Schaeffer, E.M.; Small, E.J.; Higano, C.S. Germline and Somatic Mutations in Prostate Cancer for the Clinician. J. Natl. Compr. Cancer Netw. 2019, 17, 515-521. [CrossRef] [PubMed]

30. Giri, V.N.; Knudsen, K.E.; Kelly, W.K.; Cheng, H.H.; Cooney, K.A.; Cookson, M.S.; Dahut, W.; Weissman, S.; Soule, H.R.; Petrylak, D.P.; et al. Implementation of Germline Testing for Prostate Cancer: Philadelphia Prostate Cancer Consensus Conference 2019. J. Clin. Oncol. 2020, 38, 2798-2811. [CrossRef]

31. NCCN: National Comprehensive Cancer Network. Prostate Cancer (version 2.2021). 2021. Available online: www.nccn.org/ patients (accessed on 17 February 2021).

32. De Bono, J.; Mateo, J.; Fizazi, K.; Saad, F.; Schore, N.; Sandhu, S.; Chi, K.N.; Sartor, O.; Agarwal, N.; Olmos, D.; et al. Olaparib for metastatic castration-resistant prostate cancer. N. Engl. J. Med. 2020, 382, 2091-2102. [CrossRef]

33. Schaeffer, E.; Srinivas, S.; Antonarakis, E.S.; Armstrong, A.J.; Bekelman, J.E.; Cheng, H.; D'Amico, A.V.; Davis, B.J.; Desai, N.; Dorff, T.; et al. NCCN Guidelines Insights: Prostate Cancer, Version 1.2021. J. Natl. Compr. Cancer Netw. 2021, 19, 134-143. [CrossRef]

34. Gillessen, S.; Attard, G.; Beer, T.M.; Beltran, H.; Bjartell, A.; Bossi, A.; Briganti, A.; Bristow, R.; Chi, K.; Clarke, N.; et al. Management of Patients with Advanced Prostate Cancer: Report of the Advanced Prostate Cancer Consensus Conference 2019. Eur. Urol. 2020, 77, 508-547. [CrossRef]

35. de Bono, J.S.; Mehra, N.; Scagliotti, G.V.; Castro, E.; Dorff, T.; Stirling, A.; Stenzl, A.; Fleming, M.T.; Higano, C.S.; Saad, F.; et al. Talazoparib monotherapy in metastatic castration-resistant prostate cancer with DNA repair alterations (TALAPRO-1): An open-label, phase 2 trial. Lancet Oncol. 2021, 22, 1250-1264. [CrossRef]

36. Cheng, H.H.; Pritchard, C.C.; Boyd, T.; Nelson, P.S.; Montgomery, B. Biallelic inactivation of BRCA2 in platinum-sensitive metastático castration-resistant prostate cancer. Eur. Urol. 2016, 69, 992-995. [CrossRef] [PubMed]

37. Pomerantz, M.M.; Spisák, S.; Jia, L.; Cronin, A.M.; Csabai, I.; Ledet, E.; Sartor, A.O.; Rainville, I.; O'Connor, E.P.; Herbert, Z.T.; et al. The association between germline BRCA2 variants and sensitivity to platinum-based chemotherapy among men with metastatic prostate cancer. Cancer 2017, 123, 3532-3539. [CrossRef]

38. Kantoff, P.W.; Higano, C.S.; Shore, N.D.; Berger, E.R.; Small, E.J.; Penson, D.F.; Redfern, C.H.; Ferrari, A.C.; Dreicer, R.; Sims, R.B.; et al. Sipuleucel-T immunotherapy for castration-resistant prostate cancer. N. Engl. J. Med. 2010, 363, 411-422. [CrossRef]

39. Kwon, E.D.; Drake, C.G.; Scher, H.I.; Fizazi, K.; Bossi, A.; Van den Eetwegh, A.J.; Krainer, M.; Houede, N.; Santos, R.; Mahammedi, H.; et al. Ipilimumab versus placebo after radiotherapy in patients with metastatic castration-resistant prostate cancer that had progressed after docetaxel chemotherapy (CA184-043): A multicentre, randomized, double-blind, phase 3 trial. Lancet Oncol. 2014, 15, 700-712. [CrossRef]

40. Beer, T.M.; Kwon, E.D.; Drake, C.G.; Fizazi, K.; Logothetis, C.; Gravis, G.; Ganju, V.; Polikoff, J.; Saad, F.; Humanski, P.; et al. Randomized, double-blind, phase III trial of ipilimumab versus placebo in asymptomatic or minimally symptomatic patients with metastatic chemotherapy-naïve castration-resistant prostate cancer. J. Clin. Oncol. 2017, 35, 40-47. [CrossRef] [PubMed]

41. Sweeney, C.J.; Gillessen, S.; Rathkopf, D.; Matsubara, N.; Drake, C.; Fizazi, K.; Piulats, J.M.; Wysocki, P.J.; Buchschacher, G.L.; Dos, J.; et al. IMbassador250: A phase III trial comparing atezolizumab with enzalutamide vs. enzalutamide alone in patients with metastatic castration-resistant prostate cancer (mCRPC). Abstract CT014. In Proceedings of the AACR Annual Virtual Meeting, Philadelphia, PA, USA, 27-28 April 2020. 
42. Abida, W.; Cheng, M.L.; Armenia, J.; Middha, S.; Autio, K.A.; Vargas, H.A.; Rathkoph, D.; Morris, M.J.; Danila, D.C.; Slovin, S.F.; et al. Analysis of the Prevalence of Microsatellite Instability in Prostate Cancer and Response to Immune Checkpoint Blockade. JAMA Oncol. 2019, 5, 471-478. [CrossRef] [PubMed]

43. Farolfi, A.; Fendler, W.; Iravani, A.; Haberkorn, U.; Hicks, R.; Herrmann, K.; Walz, J.; Fanti, S. Theranostics for advanced prostate cancer: Current indications and future developments. Eur. Urol. Oncol. 2019, 2, 152-162. [CrossRef] [PubMed]

44. Heck, M.M.; Tauber, R.; Schwaiger, S.; Retz, M.; D'Alessandria, C.; Mauer, T.; Gafita, A.; Wester, H.J.; Gschwend, J.E.; Weber, W.A.; et al. Treatment Outcome, Toxicity, and Predictive Factors for Radioligand Therapy with 177Lu-PSMA-I\&T in metastatic castration-resistant prostate cancer. Eur. Urol. 2019, 75, 920-926.

45. Hofman, M.S.; Emmett, L.; Sandhu, S.; Iravani, A.; Joshua, A.M.; Goh, J.C.; Pattison, D.A.; Tan, T.H.; Kirkwood, I.D.; Ng, S.; et al. [177Lu]Lu-PSMA-617 versus cabazitaxel in patients with metastatic castration-resistant prostate cancer (TheraP): A randomised, open-label, phase 2 trial. Lancet 2021, 397, 797-804. [CrossRef]

46. Sartor, O.; de Bono, J.; Chi, K.N.; Fizazi, K.; Herrmann, K.; Rahbar, K.; Tagawa, S.T.; Nordquist, L.T.; Vaishampayan, N.; ElHaddad, G.; et al. VISION Investigators. Lutetium-177-PSMA-617 for Metastatic Castration-Resistant Prostate Cancer. N. Engl. J. Med. 2021, 384. [CrossRef]

47. Wise, H.M.; Hermida, M.A.; Leslie, N.R. Prostate cancer, PI3K, PTEN and prognosis. Clin. Sci. 2017, 131, 197-210. [CrossRef] [PubMed]

48. De Bono, J.S.; De Giorgi, U.; Rodrigues, D.N.; Massard, C.; Bracarda, S.; Font, A.; Arija, J.A.; Shih, K.C.; Radavoi, G.D.; Xu, N.; et al. Randomized phase II study evaluating Akt blockade with Ipatasertib, in combination with abiraterone, in patients with metastatic prostate cancer with and without PTEN loss. Clin. Cancer Res. 2019, 25, 928-936. [CrossRef]

49. Shore, N.D.; Drake, C.G.; Lin, D.W.; Ryan, C.J.; Stratton, K.L.; Dunshee, C.; Karsh, L.I.; Kaul, S.; Kernen, K.; Pieczonka, C.; et al. Optimizing the management of castration-resistant prostate cancer patients: A practical guide for clinicians. Prostate 2020, 80, 1159-1176. [CrossRef]

50. Lorente, D.; Mateo, J.; Pérez-López, R.; De Bono, J.S.; Attard, G. Sequencing of agents in castration-resistant prostate cancer. Lancet Oncol. 2015, 16, e279-e292. [CrossRef]

51. De Wit, R.; De Bono, J.S.; Sternberg, C.N.; Fizazi, K.; Tombal, B.; Wülfing, C.; Kramer, G.; Eymard, J.C.; Bamias, A.; Carles, J.; et al. Cabazitaxel versus abiraterone or enzalutamide in prostate cancer. N. Engl. J. Med. 2019, 381, 2506-2518. [CrossRef]

52. Henriquez, I.; Spratt, D.; Gómez-Iturriaga, A.; Abuchaibe, O.; Couñago, F. Nonmetastatic castration-resistant prostate cancer: Novel agents to treat a letal disease. World J. Clin. Oncol. 2021, 12, 6-12. [CrossRef]

53. Saad, F.; Gleason, D.M.; Murray, R.; Tchekmedyian, S.; Venner, P.; Lacombe, L.; Chin, J.L.; Vinholes, J.J.; Goas, J.A.; Chen, B.; et al. A randomized, placebo-controlled trial of zoledronic acid in patients with hormone-refractory metastatic prostate carcinoma. $J$. Natl. Cancer Inst. 2002, 94, 1458-1468. [CrossRef] [PubMed]

54. Fizazi, K.; Carducci, M.; Smith, M.; Damião, R.; Brown, J.; Karsh, L.; Milecki, P.; Shore, N.; Rader, M.; Wang, H.; et al. Denosumab versus zoledronic acid for treatment of bone metastases in men with castration-resistant prostate cancer: A randomised, doubleblind study. Lancet 2011, 377, 813-822. [CrossRef] 